\title{
Fertilizing Lychee Plants with Phosphorus at Time of Planting in Brazil
}

\author{
Renato de Mello Prado, Ancélio Ricardo de Oliveira Gondim, \\ and Marcus André Ribeiro Correia
}

\author{
Department of Soils and Fertilizers, São Paulo State University, Via de Acesso Paulo Donato Castellane, \\ s/n, 14884-900 Jaboticabal, SP, Brazil \\ Correspondence should be addressed to Renato de Mello Prado,rmprado@fcav.unesp.br \\ Received 27 June 2011; Revised 22 October 2011; Accepted 25 October 2011 \\ Academic Editor: Paul Voroney
}

Copyright ( $\odot 2012$ Renato de Mello Prado et al. This is an open access article distributed under the Creative Commons Attribution License, which permits unrestricted use, distribution, and reproduction in any medium, provided the original work is properly cited.

The objective of this research was to study the effects of $\mathrm{P}$ fertilizers applied at time of planting on lychees' nutritional status and on plant growth. The treatments consisted of five doses of P: zero, 50, 100, 200, and $300 \mathrm{~g}$ of $\mathrm{P}_{2} \mathrm{O}_{5}$ per plant, furnished by triple superphosphate. Plant diameter was evaluated during two years and the plants' nutritional status on the second year. The second year foliar levels of macro and micronutrients (with the exception of $\mathrm{Zn}$ ) were increased by the P fertilizer. The orchard's initial development, especially during the second year, was also influenced by the fertilizer. The P doses of 164 and $158 \mathrm{~g}$ of $\mathrm{P}_{2} \mathrm{O}_{5}$ per plant resulted in the largest plant diameter after the first and the second year, respectively. These doses were found to be associated with a foliar P level of $<1.4 \mathrm{~g} \mathrm{~kg}^{-1}$.

\section{Introduction}

The demand for fruits has been growing all over the world in recent years due to growing awareness of the importance of a well-balanced diet for human health purposes. Thus, increasing fruit production has become an important item in the agenda of farmers in general. Lychee (Litchi chinensis Sonn) is one of the fruits the consumption of which has been growing steadily in recent years. Lychee, a fruit tree originated in China, was introduced in Brazil in 1810 [1].

Brazilian soils are, usually, of low fertility. Menzel and Simpson [2] investigated several factors capable of causing lychee plants to produce poorly and concluded that the plants' nutritional status was one of the most important. Ghosh [3] also considered plant malnutrition as the most important reason for poor productive performance of lychee.

Phosphorus is one of the most important productivitylimiting nutrients due to its role in plant metabolism. Reports by Koen et al. [4] and Vilela and Anghinoni [5], indicate the importance of $\mathrm{P}$ in productivity of lychee plants. Rai et al. [6], working on Alfisol (3.2 $\mathrm{g} \mathrm{ha}^{-1}$ of P, using a Bray I extractor) in China, showed that $220 \mathrm{~g}$ of $\mathrm{P}$ per lychee plant caused the plants to grow and produce more. They also observed a significant correlation between fruit production and P level in leaves. In an Australian study, Menzel et al. [7] suggested that the adequate level of $\mathrm{P}$ in leaves for a good production was between 1.4 and $2.2 \mathrm{~g} \mathrm{~kg}^{-1}$, as measured in branch leaves after panicle emergence in the period between May and August. Martins et al. [1] recommend 0.11 to $0.22 \mathrm{~kg}$ of fertilizers containing $2-4 \%$ of $\mathrm{P}$ for lychee plants in their first year of cultivation. In Hawaii, a recommendation of $78 \mathrm{~g}$ of $\mathrm{P}_{2} \mathrm{O}_{5}$ per lychee plant is reported by Menzel and Simpson [2].

The above data reveal an obvious lack of published information for the fertilization of lychee plants in Brazil, especially for P fertilizers [8]. The low mobility of P in the soil and the fact that the effect of $\mathrm{P}$ on plant growth is more important at the beginning of the plants' development emphasize the importance for an investigation into how to apply $\mathrm{P}$ fertilizers to lychee plants at the onset of their growth, right after the seedlings have been obtained by the marcottage method. 


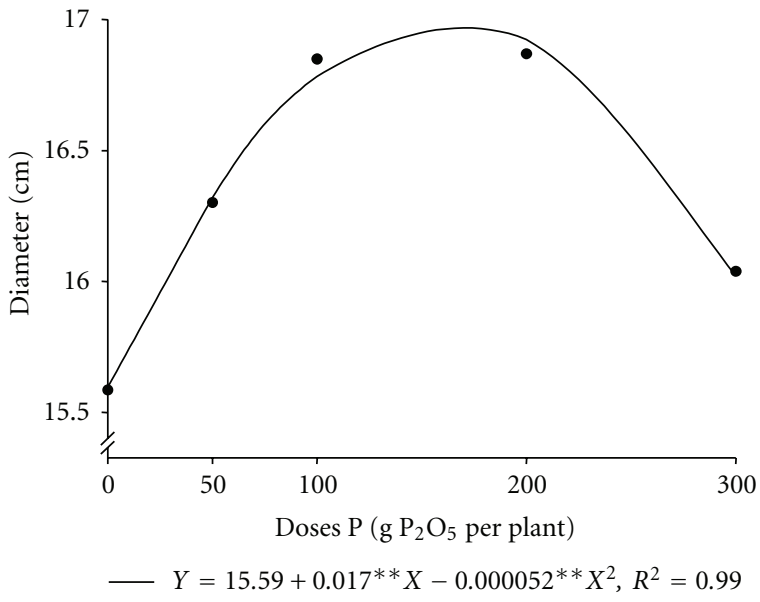

(a)

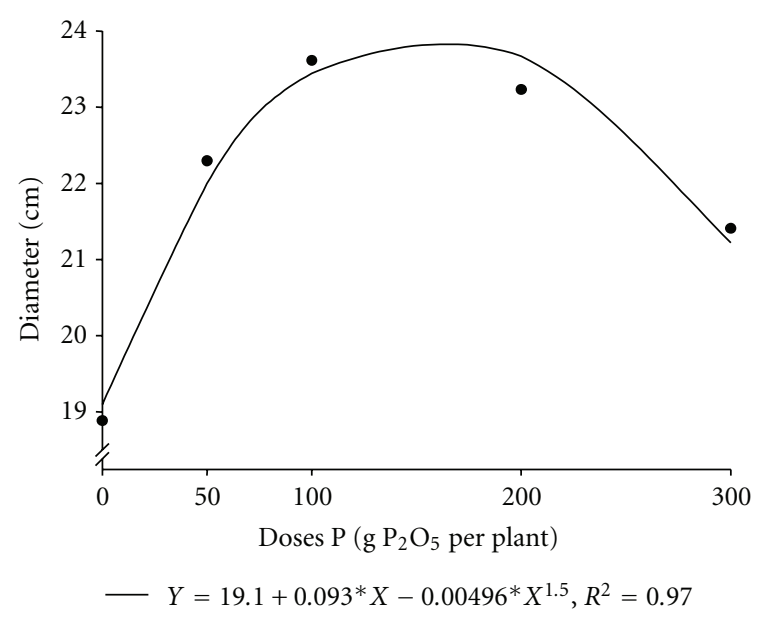

(b)

Figure 1: Effect of phosphorus applied at planting on lychee plants stem diameter at the first (a) and second (b) year after planting. ** Significant $P<0.01$ and *significant $P<0.05$.

\section{Material and Methods}

The experiment was conducted on the "Flora" farm in Uberlândia, state of Minas Gerais, Brazil, with a red-yellow latosol of clayish texture, located at $18^{\circ} 55^{\prime} 23^{\prime \prime}$ of south latitude and $48^{\circ} 17^{\prime} 19^{\prime \prime}$ of longitude. According to Köppen's classification, the climate is of the Cwa subtropical type with a short, moderate, and dry Winter and a hot and rainy Summer.

The chemical soil analyses, following the methods recommended by Raij et al. [9], were based on 20 soil samples $(0$ to $20 \mathrm{~cm})$ and yielded the following results: $\mathrm{pH}\left(\mathrm{CaCl}_{2}\right)$ : 5.2; organic matter $(\mathrm{OM}): 17 \mathrm{~g} \mathrm{dm}^{-3}$; $\mathrm{P}$ (resin): $6 \mathrm{mg} \mathrm{dm}^{-3}$; $\mathrm{K}: 0.5 \mathrm{mmol}_{\mathrm{c}} \mathrm{dm}^{-3}$, Ca: $19 ; \mathrm{mmol}_{\mathrm{c}} \mathrm{dm}^{-3} ; \mathrm{Mg} 9 \mathrm{mmol}_{\mathrm{c}} \mathrm{dm}^{-3}$; $\mathrm{H}+\mathrm{Al}: 20 \mathrm{mmol}_{\mathrm{c}} \mathrm{dm}^{-3}$; sum of bases (SB): $28.5 \mathrm{mmol}_{\mathrm{c}} \mathrm{dm}^{-3}$; cation exchange capacity (CTC): $48.5 \mathrm{mmol}_{\mathrm{c}} \mathrm{dm}^{-3}$; bases saturation (V): 59\%.

The orchard used in this experiment was planted in January 2004, with lychee plants of the "Bengal" cultivar. The spacing between plants was $6 \times 6 \mathrm{~m}$. The cuttings used to form the orchard had been produced by the vegetative method known as marcottage, due to the fact that this procedure reduces the duration of the plants juvenile period in addition to being a guarantee for the plants genetic identity [10].

The experiment was set according to a randomized complete block design with 4 replicates. Doses of $\mathrm{P}$ applied to the plants were considered the treatments and they were of $0,50,100,200$, and $300 \mathrm{~g}$ of $\mathrm{P}_{2} \mathrm{O}_{5}$ per plant, in the furrow at planting on January 2, 2004. The dose of $100 \mathrm{~g}$ of $\mathrm{P}_{2} \mathrm{O}_{5}$ per plant is indicated as suitable for lychee [8]. Triple superphosphate with $44 \%$ of $\mathrm{P}_{2} \mathrm{O}_{5}$ was used to furnish the needed $\mathrm{P}_{2} \mathrm{O}_{5}$. During the second year of the experiment, those doses were doubled and applied to the plants. Five trees were considered to form an experimental unit with the three central trees used to make the programmed measurements.

In addition to the mentioned $\mathrm{P}$ doses, each plant also received $20 \mathrm{~L}$ of cow manure $\left(\mathrm{N}: 7.4 \mathrm{~g} \mathrm{~kg}^{-1} ; \mathrm{P}=1.6 \mathrm{~g} \mathrm{~kg}^{-1}\right.$;
$\left.\mathrm{K}=23.1 \mathrm{~g} \mathrm{~kg}^{-1}\right), 5 \mathrm{~g}$ of $\mathrm{Zn}$ furnished by zinc sulfate, and $1 \mathrm{~g}$ of $\mathrm{B}$, provided by boric acid, in the furrow at planting. Cuttings developing into plants in the field were watered each 2-3 days depending on weather conditions.

In the first year, the plants were fertilized by the side-dressing method with $40 \mathrm{~g}$ of $\mathrm{N}$ and $60 \mathrm{~g}$ of $\mathrm{K}_{2} \mathrm{O}$ per plant. In the second year, the doses were $80 \mathrm{~g}$ of $\mathrm{N}$ and $100 \mathrm{~g}$ of $\mathrm{K}_{2} \mathrm{O}$. The fertilizers were placed on the soil surface, around the seedlings, at a distance of 0.3 to $0.5 \mathrm{~m}$ from the plant. The fertilizer doses were divided in three parts, applied during the rainy season (February, March, and April). Half of the $\mathrm{N}$ dose was furnished by urea and the other half by ammonium sulfate, whereas potassium was furnished by potassium chloride.

During the first and the second years of the experiment, always in January (2005 and 2006), the plants' stem diameter was measured. In the second year, leaves were taken to evaluate the plants' nutritional status. The leaf sample consisted of the central two pairs of leaflets taken from the second compound leaf, according to instructions found in Carvalho and Salomão [8]. The methodology followed to determine the amount of macro- and micronutrients in the plant tissue was that described in Bataglia et al. [11].

Based upon the results, the analysis of variance of the several parameters was made and, when necessary, a regression analysis was also carried out, viewing to establish the relations between the treatments and the values found for stem diameter and plants' nutritional status. For the statistical analysis, the SAS program [12] was employed.

\section{Results and Discussion}

Phosphorus increased plant stem diameter in a quadratic manner with the maximum values being 16.99 and $23.95 \mathrm{~cm}$ (9 and 25\% larger than those observed for the check treatment plants, thus demonstrating that the P effect on plant stem diameter occurs slowly) in the first and the second year, 


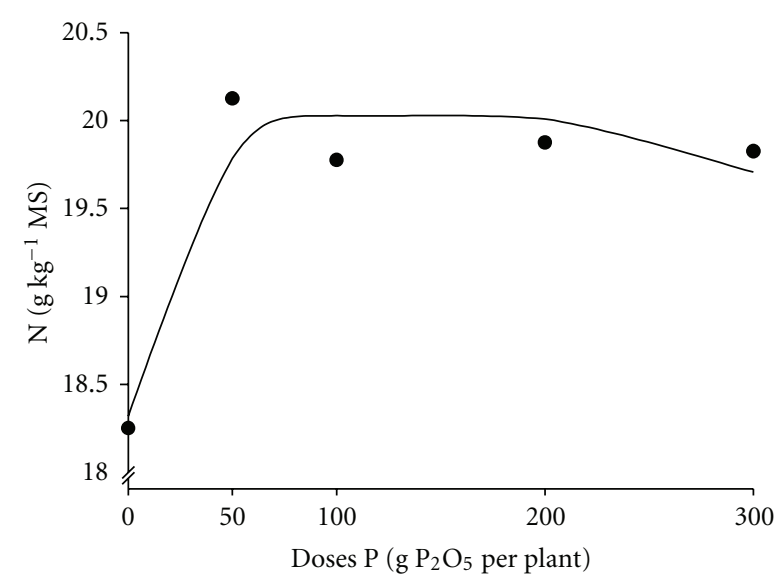

$-Y=18.32+0.295^{*} X^{0.5}-0.012406^{*} X, R^{2}=0.9$

(a)

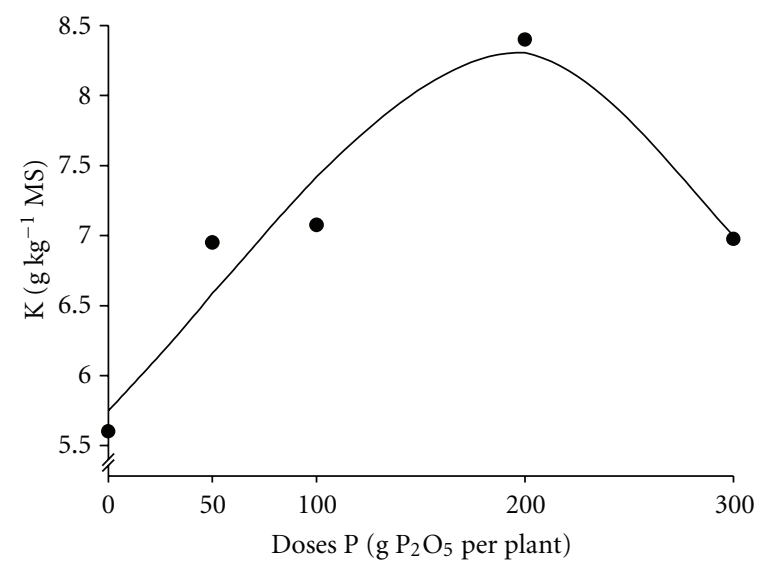

$-Y=\operatorname{EXP}\left(1.74+0.0027^{*} X-0.00000002^{*} X^{3}\right), R^{2}=0.93$

(c)

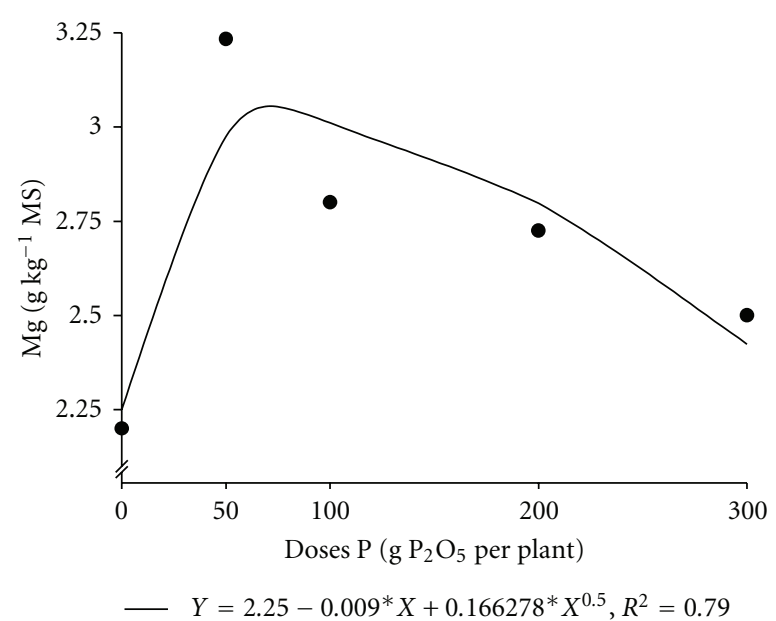

(e)

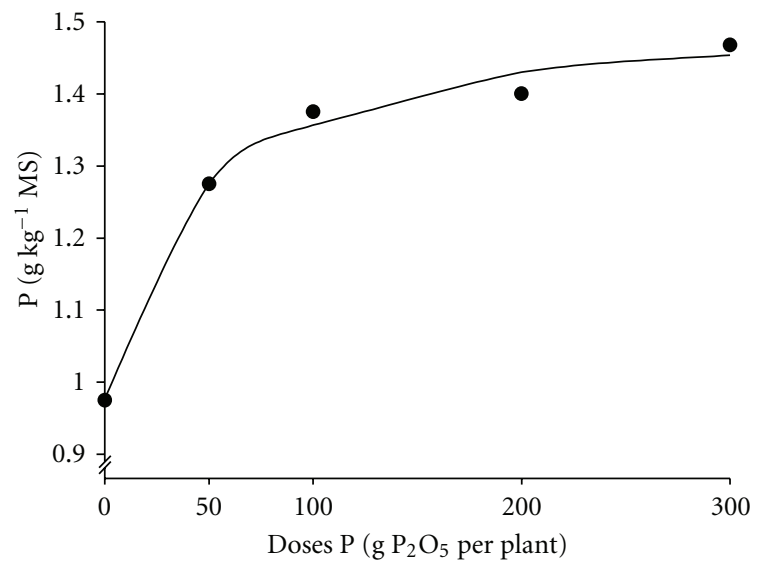

$-Y=0.98+0.0522 * X^{0.5}-0.00142 * X, R^{2}=0.99$

(b)

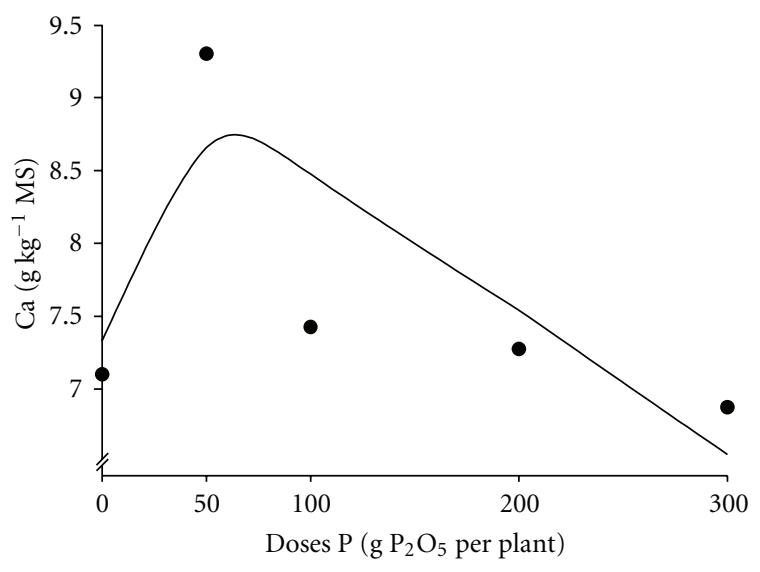

$-Y=\left(0.14+0.0003 * X-0.00563 * X^{0.5}\right)^{-1}, R^{2}=0.54$

(d)

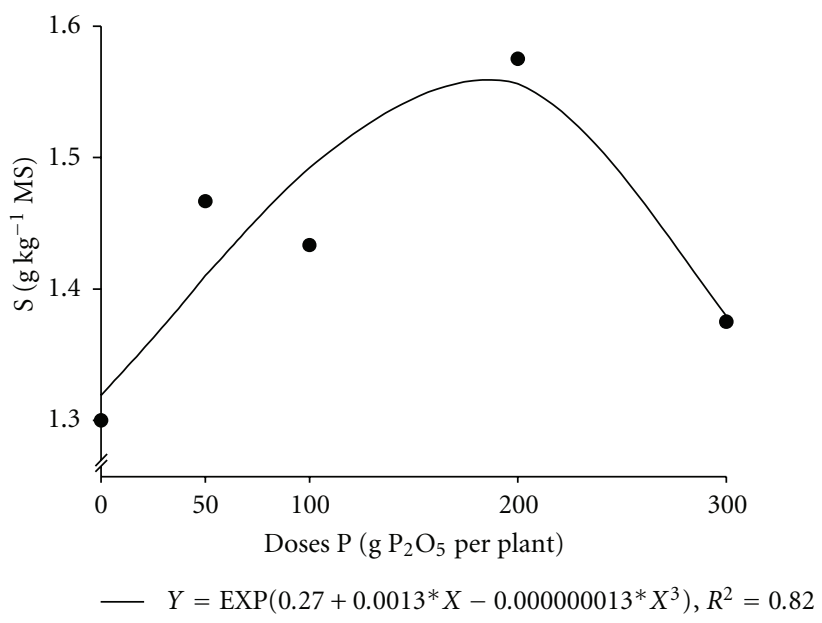

(f)

FIGURE 2: Effect of phosphorus applied at planting on lychee plants foliar levels of N (a), P (b), K (c), Ca (d), Mg (e), and S (f). * Significant $P<0.05$. 


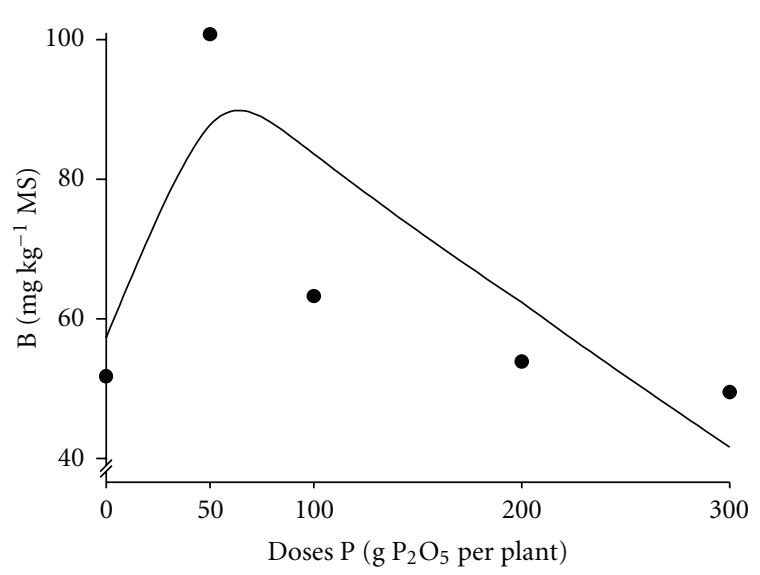

$-Y=\operatorname{EXP}\left(4.05-0.0076^{*} X+0.114689^{*} X^{0.5}\right), R^{2}=0.59$

(a)

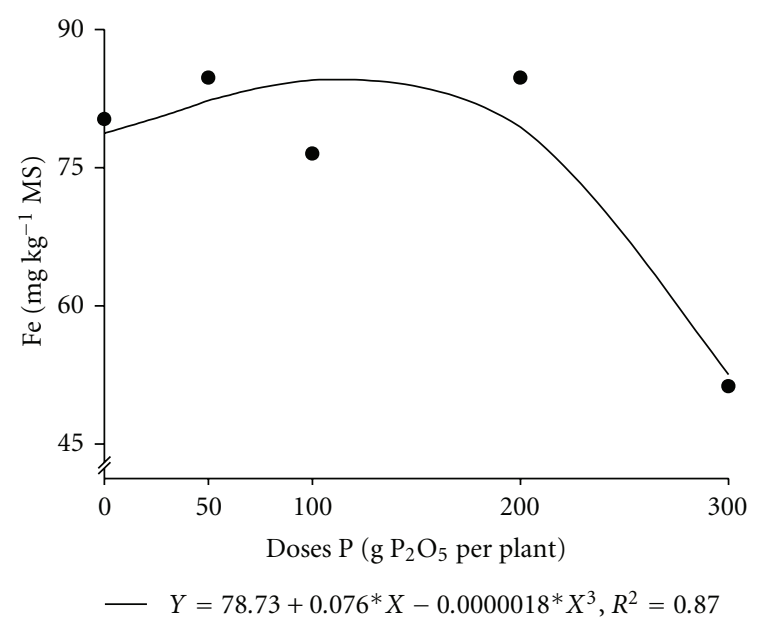

(c)

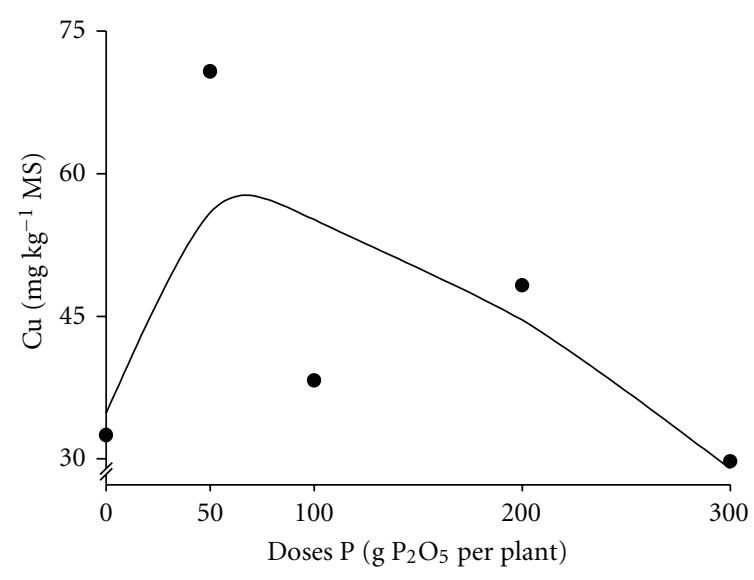

$-Y=34.79-0.3239^{*} X+5.276769^{*} X^{0.5}, R^{2}=0.53$

(b)

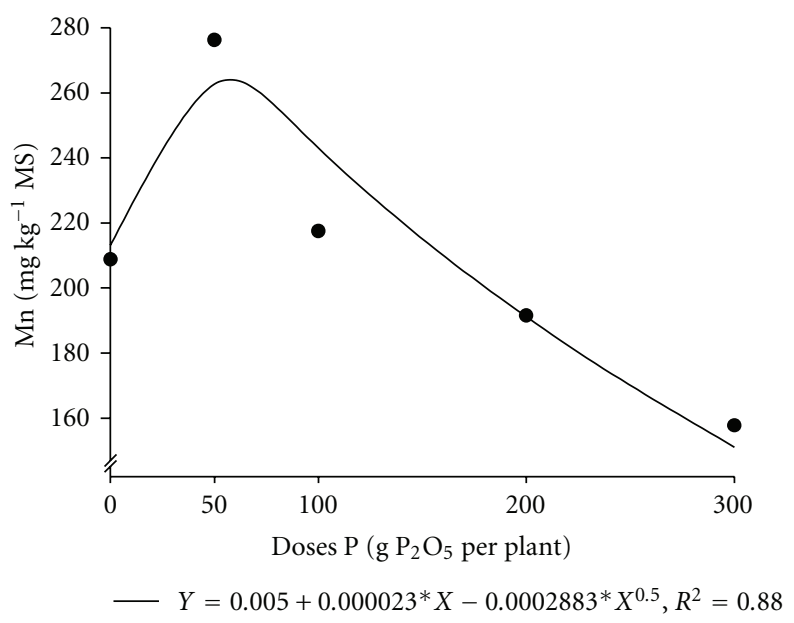

(d)

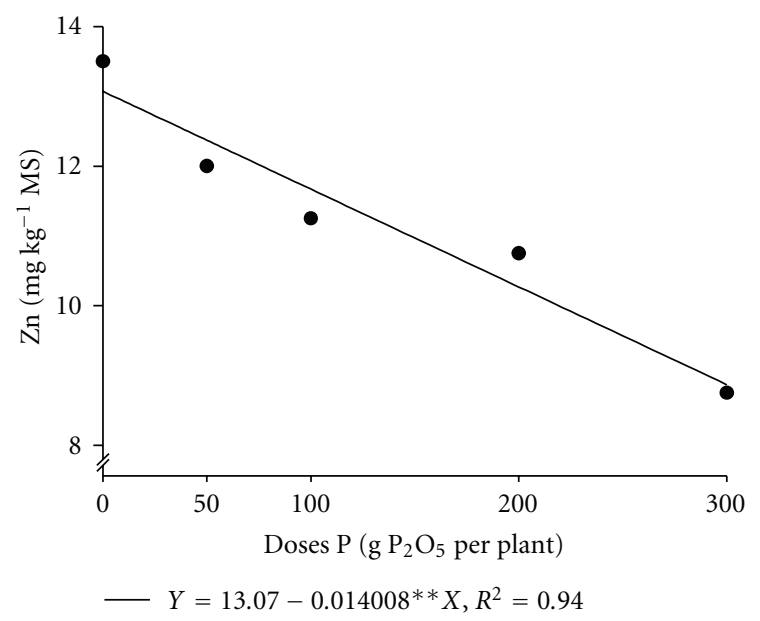

(e) 


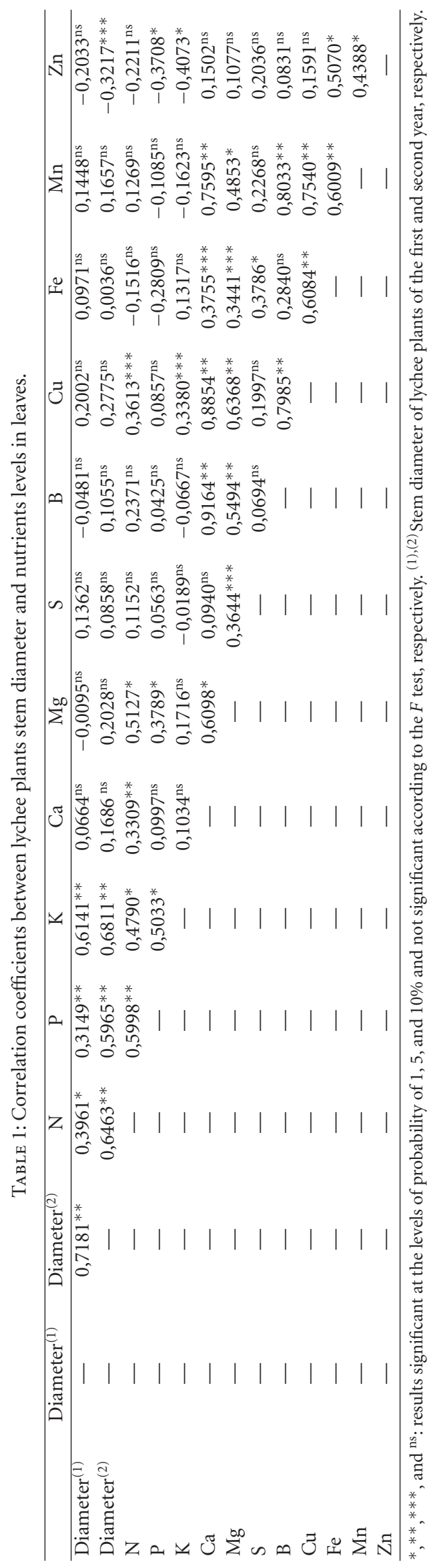


respectively. These values were associated with the $\mathrm{P}_{2} \mathrm{O}_{5}$ doses of 164 and $158 \mathrm{~g}$ per plant, respectively, (Figures 1(a) and $1(b))$. In the literature, no paper indicating the effects of $\mathrm{P}$ on lychee plant stem diameter was found. Prado [13], working with mango, also reported increased stem diameters as a consequence of fertilizing the plants with $\mathrm{P}$.

Lychee plants leaf concentrations of macro- (Figure 2) and micronutrients (Figure 3), in observations made during the second year, were affected by the application of $\mathrm{P}$ fertilizer at planting.

It was observed that the leaf contents $\mathrm{N}, \mathrm{K}, \mathrm{Ca}, \mathrm{Mg}, \mathrm{S}$, $\mathrm{B}, \mathrm{Cu}$, and $\mathrm{Mn}$ were higher than those reported by Franco [14] in a study conducted in an orchard considered to be very productive, whereas those of $\mathrm{P}, \mathrm{Fe}$, and $\mathrm{Zn}$ were smaller. These discrepancies can be ascribed to the differences of climate and soil existing between the two places where the experiments were performed.

The $\mathrm{P}$ doses used in this experiment caused increments in $\mathrm{P}$ leaf content the maximum value of which was $1.5 \mathrm{~g} \mathrm{~kg}^{-1}$ which resulted from the dose of $300 \mathrm{~g}$ of $\mathrm{P}_{2} \mathrm{O}_{5}$ per plant (Figure 2(b)). This increment in $\mathrm{P}$ leaf content was caused by the increment of $\mathrm{P}$ level in the soil.

The doses applied at planting which resulted in the highest stem diameters were (of) 164 and $158 \mathrm{~g}$ of $\mathrm{P}_{2} \mathrm{O}_{5}$ (Figures $1(\mathrm{a})$ and $1(\mathrm{~b})$ ) for the first and the second year, respectively. These doses were found to be associated with the P leaf level of $<1.4 \mathrm{~g} \mathrm{~kg}^{-1}$ (Figure 2(b)). This value is different from that indicated by Rai et al. [6] of 1.8 to $2.9 \mathrm{~g} \mathrm{~kg}^{-1}$, but within the range indicated by Menzel et al. [7] of 1.4 to $2.2 \mathrm{~g} \mathrm{~kg}^{-1}$. These differences are attributable to soil and climatic conditions in which the experiments were carried out as well as the age of the orchards used for the research.

The $\mathrm{P}$ doses caused increments in the levels of $\mathrm{N}, \mathrm{K}, \mathrm{Ca}$, $\mathrm{Mg}$, and S, the highest values of which were of 20.1, 8.3, 8.7, 2.9 , and $1.6 \mathrm{~g} \mathrm{~kg}^{-1}$, respectively. These values were found to be associated with doses of $142,198,55$, and $183 \mathrm{~g}$ of $\mathrm{P}_{2} \mathrm{O}_{5}$ per plant, respectively, (Figures 2(a), 2(c), 2(d), 2(e), and $2(\mathrm{f}))$. The levels of the micronutrients $\mathrm{B}, \mathrm{Cu}, \mathrm{Fe}$, and $\mathrm{Mn}$ reached the maximum values of $88,56,85$, and $264 \mathrm{mg} \mathrm{kg}^{-1}$ associated with doses per plant of $\mathrm{P}_{2} \mathrm{O}_{5}$ of $56,66,118$, and $39 \mathrm{~g}$, respectively, (Figures 3(a), 3(b), 3(c), and 3(d)). On the other hand, $\mathrm{Zn}$ level in plant leaves decreased with the doses of $\mathrm{P}$ applied to the soil (Figure 3(e)). The level of those nutrients in the plant leaves is attributed to the effect $P$ causes on root growth. Vilela and Anghinoni [5] report having observed that $\mathrm{P}$ contributes to the elongation of the root system which, with longer and thinner roots, is thus better equipped to exploit larger volumes of soil around it. Table 1 shows that the foliar levels of $\mathrm{P}$ correlated positively with the levels of the other nutrients such as $\mathrm{N}, \mathrm{K}$, and $\mathrm{Mg}$.

It was observed that the stem diameter of lychee plants at the beginning of their development is very dependent on the plants' nutritional status in terms of $\mathrm{N}, \mathrm{P}$, and $\mathrm{K}$ as indicated by the correlation coefficients of the two growing seasons (Table 1). It is also seen that, in the second year, the correlation between the $\mathrm{Zn}$ level in leaves and plant stem diameter was a negative one. $\mathrm{P}$ and $\mathrm{Zn}$ levels in leaves also showed a negative correlation according to the explanation proposed by Safaya [15], P is capable of inhibiting Zn absorption because it reduces the translocation of the micronutrient through the root endodermis and epidermis. This situation is likely to hamper the lychee plants' nutritional status in terms of $\mathrm{Zn}$, making necessary a complementary furnishing of $\mathrm{Zn}$ to the plants to avoid nutritional disorders.

\section{Conclusions}

(1) Fertilizing lychee plants at planting time with P increased the foliar levels of macro- and micronutrients, with the exception of $\mathrm{Zn}$, according to measurements made in the second year. The orchard initial development, especially that of the second year after planting, was also promoted by $\mathrm{P}$ fertilizer applied at planting.

(2) The doses of 164 and $158 \mathrm{~g}$ of $\mathrm{P}_{2} \mathrm{O}_{5}$ per plant were those which, in the first and in the second year, respectively, permitted the highest values of plant stem diameter. These doses were found to be associated with the P leaf level of $<1.4 \mathrm{~g} \mathrm{~kg}^{-1}$.

\section{References}

[1] A. B. G. Martins, D. C. Bastos, and E. J. Scaloppi Jr., Lichieira (Litchi chinensis Sonn), Sociedade Brasileira de Fruticultura, Jaboticabal, Brazil, 2001.

[2] C. M. Menzel and D. R. Simpson, "Lychee nutrition: a review," Scientia Horticulturae, vol. 31, no. 3-4, pp. 195-224, 1987.

[3] S. P. Ghosh, "Word trade in litchi: past, present and future," Acta Horticulturae, Wageningen, vol. 558, pp. 23-30, 2001.

[4] T. J. Koen, W. Langenegger, and G. Smart, "Determination of fertilizers requeriments of litchi trees," Information Bulletin Citrus and Subtropical Fruit Research Institute, Merbein, vol. 103, pp. 9-12, 1981.

[5] L. Vilela and I. Anghinoni, "Morfologia do sistema radicular e cinética de absorção de fósforo em cultivares de soja afetadas pela interação alumínio fósforo," Revista Brasileira de Ciência do Solo, Viçosa, vol. 8, pp. 91-96, 1984.

[6] M. Rai, P. Dey, K. K. Gangopadhyay et al., "Influence of nitrogen, phosphorus and potassium on growth parameters, leaf nutrient composition and yield of litchi (Litchi chinensis)," Indian Journal of Agricultural Sciences, vol. 72, no. 5, pp. 267270, 2002.

[7] C. M. Menzel, M. L. Carseldine, G. F. Haydon, and D. R. Simpson, "A review of existing and proposed new leaf nutrient standards for lychee," Scientia Horticulturae, vol. 49, no. 1-2, pp. 33-53, 1992.

[8] C. M. Carvalho and L. C. C. Salomão, "Cultura da lichieira," Tech. Rep. 43, Viçosa: Universidade Federal de Viçosa, 2000.

[9] B. V. Raij, J. C. Andrade, H. Cantarella, and J. A. Quaggio, Análise Química Para Avaliação da Fertilidade de Solos Tropicais, Campinas: Instituto Agronômico, 2001.

[10] R. A. Andrade, A. B. G. Martins, and I. V. M. Oliveira, "Influência do substrato na germinação de sementes de lichia," Revista Brasileira de Fruticultura, Jaboticabal, vol. 26, pp. 375376, 2004.

[11] O. B. Bataglia, A. M. C. Furlani, J. P. F. Teixeira, P. R. Furlani, and J. R. Gallo, "Métodos de análise química de plantas," Tech. Rep. 78, Campinas: Instituto Agronômico, 1983. 
[12] SAS Institute, SAS Software, SAS Institute, Cary, NC, USA, 5th edition, 1985.

[13] R. de Mello Prado, "Phosphorus effects in the nutrition and growth of developing mango plants," Journal of Plant Nutrition, vol. 33, no. 14, pp. 2041-2049, 2010.

[14] C. F. Franco, R. M. Prado, L. F. Braghirolli, R. M. Leal, E. G. Perez, and L. M. Romualdo, "Uso da poda e de diferentes diâmetros de alporques sobre o desenvolvimento e o acúmulo de nutrientes de mudas de lichieira," Revista Brasileira de Fruticultura, Jaboticabal, vol. 27, pp. 491-494, 2005.

[15] N. M. Safaya, "Phosphorus-zinc interaction in relation to absorption rates of phosphorus, zinc, copper, manganese, and iron in corn," Soil Science of Society American Journal, Madison, vol. 40, pp. 719-722, 1976. 

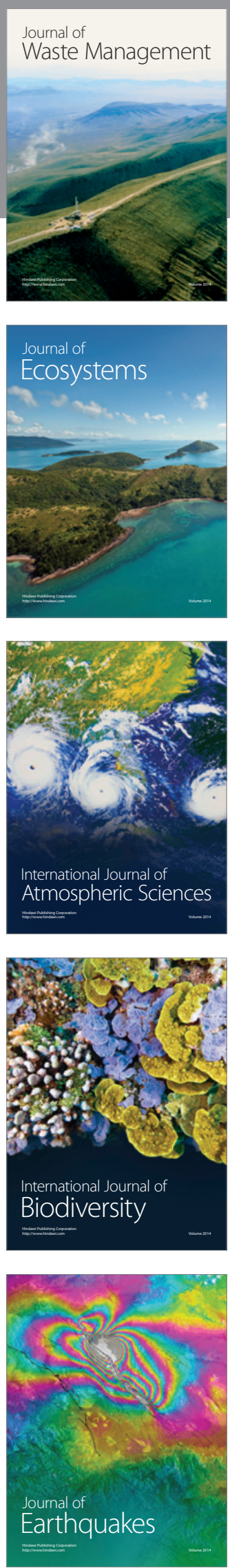
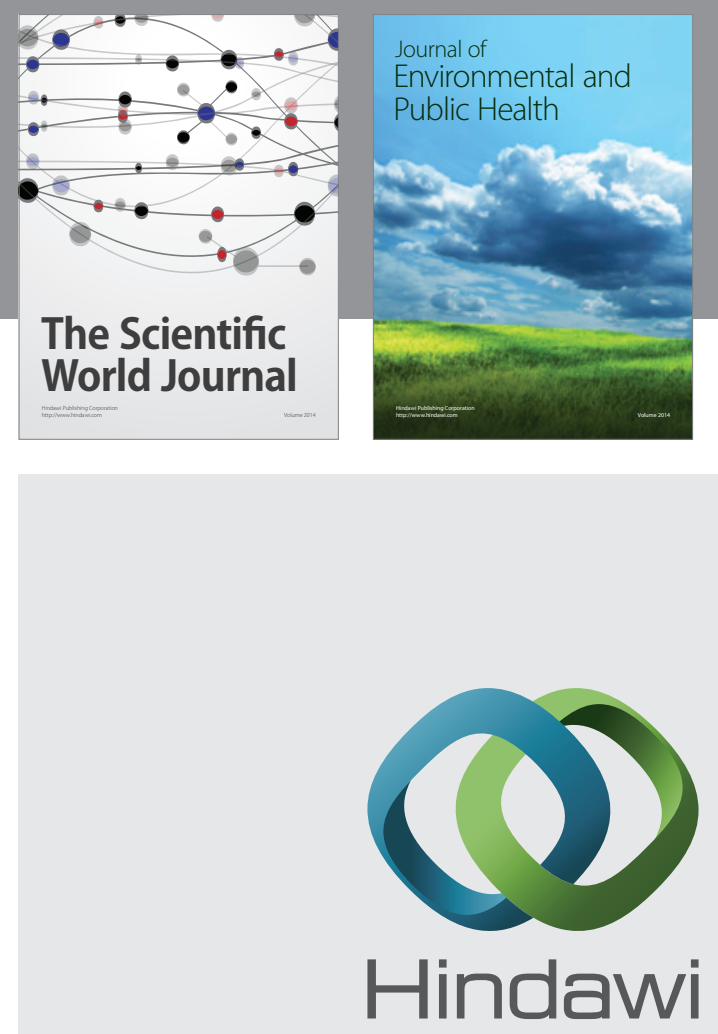

Submit your manuscripts at

http://www.hindawi.com
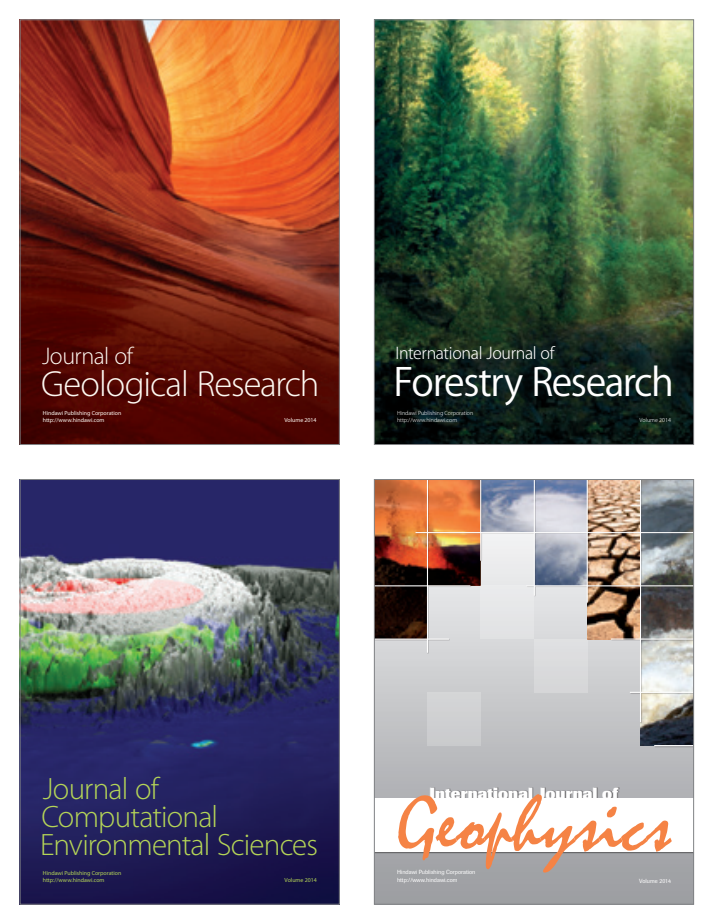
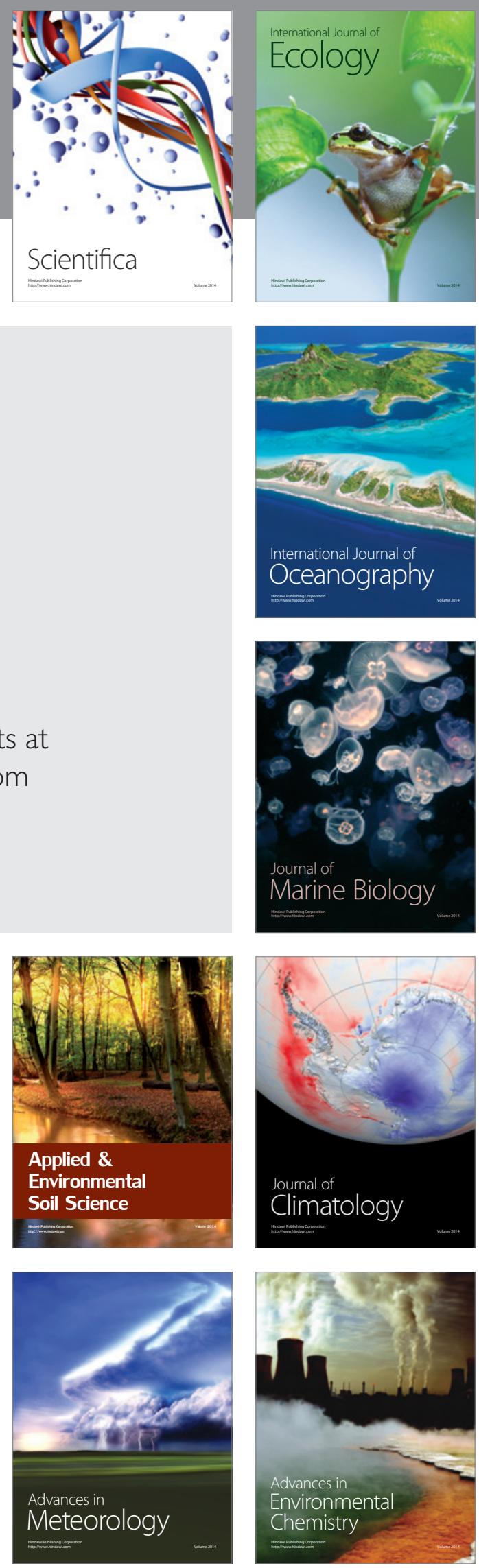